\title{
Biochemical and Physiological Characterization of Colony Form Variants in Xenorhabdus spp. (Enterobacteriaceae)
}

\author{
By N. E. BOEMARE $\dagger$ AND R. J. AKHURST* $\ddagger$ \\ Division of Entomology, CSIRO, Stowell Avenue, Hobart, Tasmania 7000, Australia
}

(Received 16 July 1987)

Primary and secondary form variants of Xenorhabdus isolated from 21 strains (13 species) of Steinernematidae and Heterorhabditidae were tested for 240 biochemical and physiological characters. Primary form variants, isolated from the infective stage nematodes, could always be distinguished from the secondary by adsorption of neutral red from MacConkey agar. Lecithinase, antibiotic activity and/or adsorption of bromothymol blue were useful for distinguishing the variants of most strains. The variants of all strains also differed for other characteristics but the distinguishing characteristics varied from strain to strain. The importance of including both variants of each strain and of using appropriate methods in the study of Xenorhabdus taxonomy was demonstrated.

\section{INTRODUCTION}

Xenorhabdus spp. are bacteria mutualistically associated with insect-pathogenic nematodes of the families Steinernematidae and Heterorhabditidae (Thomas \& Poinar, 1979; Akhurst, $1982 a, 1983)$. The infective stage of the nematodes is a third-instar juvenile with a closed intestine in which the nematode carries only its bacterial symbiont (Poinar, 1966; Akhurst, 1983; Bird \& Akhurst, 1983). The nematodes are attracted to insect hosts (Bedding \& Akhurst, 1975) and enter through natural openings (Poinar, 1979) and, in the case of Heterorhabditis spp., intersegmental membranes (Bedding \& Molyneux, 1982). The nematodes release a toxin (Boemare et al., 1982; Burman, 1982), an inhibitor of the insect inducible immune system (Götz et al., 1981) and their insect-pathogenic bacterial symbiont (Poinar \& Thomas, 1967; Milstead, 1979; Akhurst, 1982c) into the haemocoel, thus killing the host. The symbiont multiplies in the killed host and promotes nematode reproduction by providing nutrients and antibiotics to inhibit the growth of many other micro-organisms (Poinar \& Thomas, 1966; Akhurst, 1982b). Two or more weeks after death of the host, up to 0.5 million infective nematodes per $g$ of host are produced and emigrate from the cadaver to locate new hosts.

Only two species have been described in the genus Xenorhabdus, Xenorhabdus nematophilus (symbiotic with Steinernematidae) and Xenorhabdus luminescens (symbiotic with Heterorhabditidae) (Thomas \& Poinar, 1979). However, Akhurst (1983) recognized four groups among the symbionts of Steinernema spp. (syn. Neoaplectana, Wouts et al., 1982) and described three of them as subspecies of $X$. nematophilus. The subspecies nematophilus, bovienii and poinarii contained the symbionts of Steinernema feltiae (syn. N. carpocapsae, Wouts et al., 1982), Steinernema bibionis and Steinernema glaseri, respectively. The fourth group, symbionts of two undescribed Steinernema spp., was subsequently described as $X$. nematophilus subsp. beddingii (Akhurst, 1986b).

The genus Xenorhabdus was placed in the family Enterobacteriaceae (Thomas \& Poinar, 1979) although no strains reduce nitrate and one species, $X$. nematophilus, is negative for catalase. They are also exceptional for Enterobacteriaceae in having polycrystalline inclusions and, in

† Present address: Laboratoire de Pathologie Comparée, Université des Sciences, Montpellier, France.

$\ddagger$ Present address: CSIRO, Division of Entomology, GPO Box 1700, Canberra ACT 2601, Australia. 
$X$. luminescens only, membranous structures that may be photosomes, the source of their bioluminescence (Boemare et al., 1983; Boemare, 1983). Although Xenorhabdus is differentiated from other genera of Enterobacteriaceae by its low DNA-DNA relatedness $(<15 \%$; Grimont et al., 1984), the enterobacterial common antigen has been detected in Xenorhabdus spp. (Ramia et al., 1982).

Akhurst (1980) demonstrated that Xenorhabdus produces two colony types on agar media. One type, isolated from the intestine of infective-stage nematodes, was designated the primary form, and is unstable in vitro, and occasionally in vivo, producing the secondary form. In general, the primary form differs from the secondary in colony morphology and adsorption of dyes from agar media (Akhurst, 1980, 1983, 1986a, b) and in producing antimicrobial compounds (Akhurst, $1982 b$ ). The primary form is also better in its ability to provide nutrients for the nematodes in insects or in monoxenic culture on artificial media (Akhurst, 1980; Bedding, 1981, 1984).

Several workers who have studied Xenorhabdus spp. have had great difficulty in defining precisely their bacteriological characteristics because of several variable characters (Poinar $e t$ al., 1971; Thomas \& Poinar, 1979, 1983; Akhurst, 1982c, 1983; Boemare, 1983; Farmer, 1984; Grimont et al., 1984). Some strains did not give consistent results and some tests had to be conducted over or after a longer period than is normal for Enterobacteriaceae. One of the reasons for this is probably the dimorphism revealed by Akhurst (1980). This paper is a report of a study of Xenorhabdus in which 240 characters of primary and secondary form variants of Xenorhabdus isolated from 21 strains (13 species) of Steinernematidae and Heterorhabditidae were examined. This study was aimed at defining the phenotypic characteristics of the variants and providing an explanation for differences in the results of earlier studies by several workers.

\section{METHODS}

Bacterial strains. Sources of nematodes from which the bacteria were isolated are listed in Table 1.

Primary forms of the bacteria were isolated from infective stage nematodes by maceration (Akhurst, 1980) or, in the case of the French strains, by the hanging-drop technique (Poinar \& Thomas, 1967). Secondary forms were isolated from in vitro monoxenic cultures established with axenic nematodes and the primary form of the symbiont. Samples from these cultures were streaked onto nutrient agar (NA) or NBTA (NA $+0.0025 \%$ bromothymol blue $+0.004 \%$ triphenyltetrazolium chloride; Akhurst, 1980) and colonies that differed from the parent strain in morphology or, on NBTA, in colour were selected as secondary form.

Stock cultures of the bacteria were maintained on yeast-extract/salts (YS) agar, containing $\left(1^{-1}\right): 0.5 \mathrm{~g}$ $\mathrm{NH}_{4} \mathrm{H}_{2} \mathrm{PO}_{4}, 0.5 \mathrm{~g} \mathrm{~K}_{2} \mathrm{HPO}_{4}, 0.2 \mathrm{~g} \mathrm{MgSO}_{4} .7 \mathrm{H}_{2} \mathrm{O}, 5.0 \mathrm{~g} \mathrm{NaCl}, 5.0 \mathrm{~g}$ yeast extract, $12 \mathrm{~g}$ agar (Dye, 1968) at $12{ }^{\circ} \mathrm{C}$ and subcultured monthly. Each week, samples were streaked onto NA or NBTA and cultured at $28^{\circ} \mathrm{C}$ to provide inoculum for the taxonomic tests. Before and after each test, cultures were streaked onto NBTA to confirm that there had been no change from one form to the other.

Morphological characterization. Bacteria from $24 \mathrm{~h}$ YS broth (Dye, 1968) cultures $\left(28^{\circ} \mathrm{C}\right)$ were used for the Gram stain and assessed for motility by microscopic examination.

Biochemical and physiological characterization. All tests were carried out at $28^{\circ} \mathrm{C}$. Each isolate was subjected to each test on three separate occasions. With the exception of tests for acidification and assimilation, most tests were conducted using the same methods as Akhurst (1983). The following modifications of the methods used by Akhurst (1983) were made. Milk agar was prepared with equal volumes of skim milk and double-strength NA. Tweens $20,40,60,80$ and 85 were added to Sierra's medium (Sierra, 1957) to a final concentration of $0.5 \%$ to avoid inhibition of some strains. The tests for production of indolpyruvic and phenylpyruvic acids from tryptophan and phenylalanine respectively were conducted on $5 \mathrm{~d}$ cultures; ferric perchloride ( $10 \%$ in aqueous solution) and acidified ferric ammonium sulphate were used as reagents for these tests so that their sensitivities could be compared. In addition, several other tests were carried out. These were tests for protease on egg albumin agar $(1.25 \%, w / v$, albumin in tryptone agar), on Hammarsten casein agar (Merck), and on gelatin nutrient agar (Daguet, 1972; Skerman, 1967), lipase on tributyrin agar, glycogen hydrolysis, and dextran or levan production on NA with $5 \%$ sucrose.

After incubation of cultures on milk agar, casein agar, egg albumin agar and gelatin nutrient agar, plates were flooded with mercuric chloride reagent (Frazier, 1926) to confirm that clearing was due to proteolysis.

API 20E and API 20NE strips (API System) were used to compare with the results obtained by the methods above.

Carbon source utilization was determined with API CH, API AO and API AA strips over $10 \mathrm{~d}$. To prevent contamination, all the carriers containing the strips were sterilized by UV irradiation and sterile water was used to provide moisture. The strips were inoculated in a laminar-flow sterile work station and placed in the sterile carriers 
Table 1. Sources of bacteria

\begin{tabular}{|c|c|c|c|c|}
\hline \multirow[b]{2}{*}{ Group } & \multirow{2}{*}{$\begin{array}{c}\text { Bacterial } \\
\text { strain }\end{array}$} & \multicolumn{2}{|l|}{ Associated nematode } & \multirow{2}{*}{$\begin{array}{l}\text { Geographical } \\
\text { source }\end{array}$} \\
\hline & & Species & Strain & \\
\hline A & $\begin{array}{l}\mathrm{C} 1 \\
\mathrm{HI} \\
\text { Q614 }\end{array}$ & $\begin{array}{l}\text { H. heliothidis } \\
\text { Heterorhabditis sp. } \\
\text { Heterorhabditis sp. }\end{array}$ & $\begin{array}{l}\text { NC } \\
\text { Italian } \\
\text { HQ614 }\end{array}$ & $\begin{array}{l}\text { USA } \\
\text { Italy } \\
\text { Australia }\end{array}$ \\
\hline B & $\begin{array}{l}\mathrm{A} 24 \\
\mathrm{~F} 1 \\
\mathrm{NC} 116\end{array}$ & S. feltiae & $\begin{array}{l}\text { Agriotos } \\
\text { Plougastel } \\
\text { NC116 }\end{array}$ & $\begin{array}{l}\text { USSR } \\
\text { France } \\
\text { USA }\end{array}$ \\
\hline $\mathrm{C}$ & $\begin{array}{l}\mathrm{NC} 32 \\
\mathrm{NC} 33 \\
\mathrm{NC} 40\end{array}$ & $S$. glaseri & $\begin{array}{l}\mathrm{NC} 32 \\
\mathrm{NC} 33 \\
\mathrm{NC} 40\end{array}$ & $\begin{array}{l}\text { USA } \\
\text { USA } \\
\text { USA }\end{array}$ \\
\hline D & $\begin{array}{l}\text { F5 } \\
\text { F7 } \\
\text { N60 } \\
\text { Umeå }\end{array}$ & S. bibionis & $\begin{array}{l}\text { Berry } \\
\text { Champagne } \\
\text { N60 } \\
\text { Umeå }\end{array}$ & $\begin{array}{l}\text { France } \\
\text { France } \\
\text { Australia } \\
\text { Sweden }\end{array}$ \\
\hline $\mathrm{E}$ & $\begin{array}{l}\text { Dan } \\
\text { F9 } \\
\text { SK2 } \\
\text { Q58 } \\
\text { W2 } \\
\text { F3 } \\
\text { Q1 } \\
\text { W1 }\end{array}$ & $\begin{array}{l}\text { S. affinis } \\
\text { Steinernema } \text { sp. } \\
\text { S. kraussei } \\
\text { Steinernema } \text { sp. M } \\
\text { Steinernema } \text { sp. W2 } \\
\text { Steinernema } \text { sp. } \\
\text { Undescribed genus (Steinernematidae) } \\
\text { Steinernema } \text { sp. W1 }\end{array}$ & $\begin{array}{l}\text { Normandie } \\
\text { Q58 } \\
\text { Picardie } \\
\text { Q1 }\end{array}$ & $\begin{array}{l}\text { Denmark } \\
\text { France } \\
\text { Czechoslovakia } \\
\text { Australia } \\
\text { Australia } \\
\text { France } \\
\text { Australia } \\
\text { Australia }\end{array}$ \\
\hline
\end{tabular}

which were then closed before removal from the work station. Two minimal media were used for the inoculation of these strips: the defined medium API LRA provided by API and the same medium supplemented with the five growth factors for Xenorhabdus recognized by Grimont et al. (1984) (nicotinic acid and p-aminobenzoic acid at $1 \mu \mathrm{g} \mathrm{ml}^{-1}$, serine, tyrosine and proline at $20 \mu \mathrm{g} \mathrm{ml}^{-1}$ ). Assimilations of acetate, citrate and DL-lactate were also assessed by the method of Dye (1968).

Acid production from carbohydrates was assessed over $10 \mathrm{~d}$ with API $50 \mathrm{CH}$ strips inoculated with the bacteria suspended in API $50 \mathrm{CHE}$ medium. Acid production from D-fructose, gluconate, inositol, 5-keto-gluconate, ribose, salicin, sorbitol, melezitose and trehalose was also tested in peptone water with $1 \%(\mathrm{w} / \mathrm{v})$ of the carbon source and using bromocresol purple as the indicator. Aesculin hydrolysis was tested in the medium used by Akhurst (1983); a positive result was recorded upon the production of brown coloration although the medium was also examined under UV light $(254 \mathrm{~nm}$ and $366 \mathrm{~nm})$ for the disappearance of fuorescence.

Antimicrobial activity was tested by the method of Akhurst (1982b) using Micrococcus luteus as the indicator organism. Pathogenicity was tested by injection of suspensions of 100 and 1000 cells (total cell count) in Ringer's solution into the haemocoel of Galleria larvae. Mortality was recorded after $3 \mathrm{~d}$ at $28{ }^{\circ} \mathrm{C}$.

Bioluminescence was assessed by observing $4 \mathrm{~d}$ NA cultures in a photographic darkroom (allowing $10 \mathrm{~min}$ for the observer's eyes to adapt to the darkness). The bioluminescence of the Heterorhabditis group was further tested by the scintillation count method of Grimont et al. (1984).

\section{RESULTS}

Primary form variants, except for the group A strains (Table 1), which were sticky and gummy, produced colonies on agar that were very difficult to disperse in liquids. All secondary form variants could be dispersed without great difficulty.

Bioluminescence as assessed by observation in the darkroom was strongest in variant $\mathrm{Cl} / 1$, less in $\mathrm{HI} / 1$, weak in $\mathrm{Cl} / 2$ and not detected in $\mathrm{HI} / 2$ (this notation indicates the form, i.e. $/ 1$ is primary, $/ 2$ is secondary). Neither variant of strain Q614 was bioluminescent. The scintillation count method confirmed the lack of bioluminescence in the variants of strain Q614 but demonstrated a small degree of bioluminescence in variant $\mathrm{HI} / 2$. For bacterial suspensions with an optical density of 11.0 (measured by scattering) the following readings were obtained (c.p.m.): $\mathrm{Cl} / 1,>10^{6} ; \mathrm{Cl} / 2,75700 \pm 4 ; \mathrm{HI} / 1,470000 \pm 1 ; \mathrm{HI} / 2,4811 \pm 5 ; \mathrm{Q} 614 / 1,49 \pm 14$; 
Table 2. General characteristics distinguishing forms of Xenorhabdus strains

Biochemical test or physiological characteristic

Simmons citrate (synthetic medium)

Urease

Phenylpyruvic acid from phenylalanine agar

Indolpyruvic acid from tryptophan agar*

Aesculin hydrolysis

Pigmentation $\ddagger$

Dye adsorption:

BTB from NBTA§

Neutral red from MacConkey agar||

Production of antimicrobial compounds

Egg Yolk Agar:

Halo precipitation (lecithinase)

Pearly layer (lipase)

DNAase

Proteolysis:

Skim milk agar

Casein 1

Albumin

Gelatin \#

Lipolysis**:

Tween 20

Tween 40

Tween 60

Tween 80

Tween 85

Tributyrin

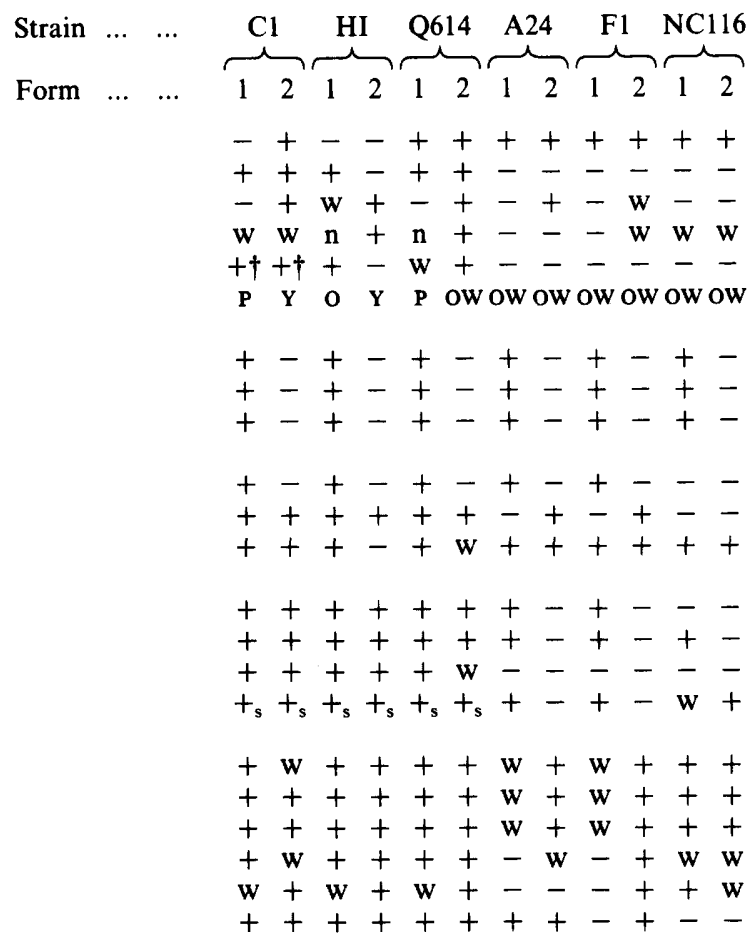

Q614/2, $32 \pm 18$; the distilled water control gave a reading of $38 \pm 16$. A suspension of variant Q614/1 with an OD of 31.0 gave only $44 \pm 15$ c.p.m. and one of Q614/2 with an OD of 100 gave only $33 \pm 17$ c.p.m. None of the bacteria isolated from steinernematid nematodes were bioluminescent.

The primary form variants of Groups A, C and D and of strain Q1 produced pigments after $4 \mathrm{~d}$ that diffused in solid and liquid media (pigmentation was most pronounced on complex media such as egg yolk agar, skim milk agar, etc., and in synthetic liquid media). Only the variants of strain Dan showed little difference in pigmentation. The secondary form variants of Group A produced different colour from the primary forms. Variant Q614/1 was salmon pink and Q614/2 off-white, HI/1 was orange to pink (rose) and $\mathrm{HI} / 2$ lemon yellow. Variant $\mathrm{C1} / 1$ was pink (carmine) when grown in API LRA with a carbon source added or on complex media, but yellow on NA or YS agar, while $\mathrm{Cl} / 2$ remained yellow under all conditions used. In all other pigmented strains, the secondary form variants were off-white without distinguishable diffusion into the media. Group B strains and strain W1 were not pigmented (off-white and cream colonies, respectively). In all strains primary form colonies were more opaque than secondary.

On skim milk agar a halo of precipitation was observed about secondary form variants and about primary forms of Groups A and C, and of strains Q58, W1, W2 and Q1. This precipitation was either not observed about primary form colonies of other strains or it was produced early (1$3 \mathrm{~d}$ ) and subsequently disappeared. For tests on egg yolk agar, skim milk agar and casein agar, flooding the plates with mercuric chloride to ensure that the clearing zones were the result of proteolytic activity was found to be necessary. Proteolytic activity was always strongest in the primary variant of each strain.

Ferric perchloride was found to be more sensitive than acidified ferric ammonium sulphate for detecting differences between strains and variants growing on phenylalanine and tryptophan agars. Phenylpyruvic acid, but not indolpyruvic acid, production tended to be characteristic of secondary form variants in those strains where it was detected (Table 2). 
Table 2. Continued
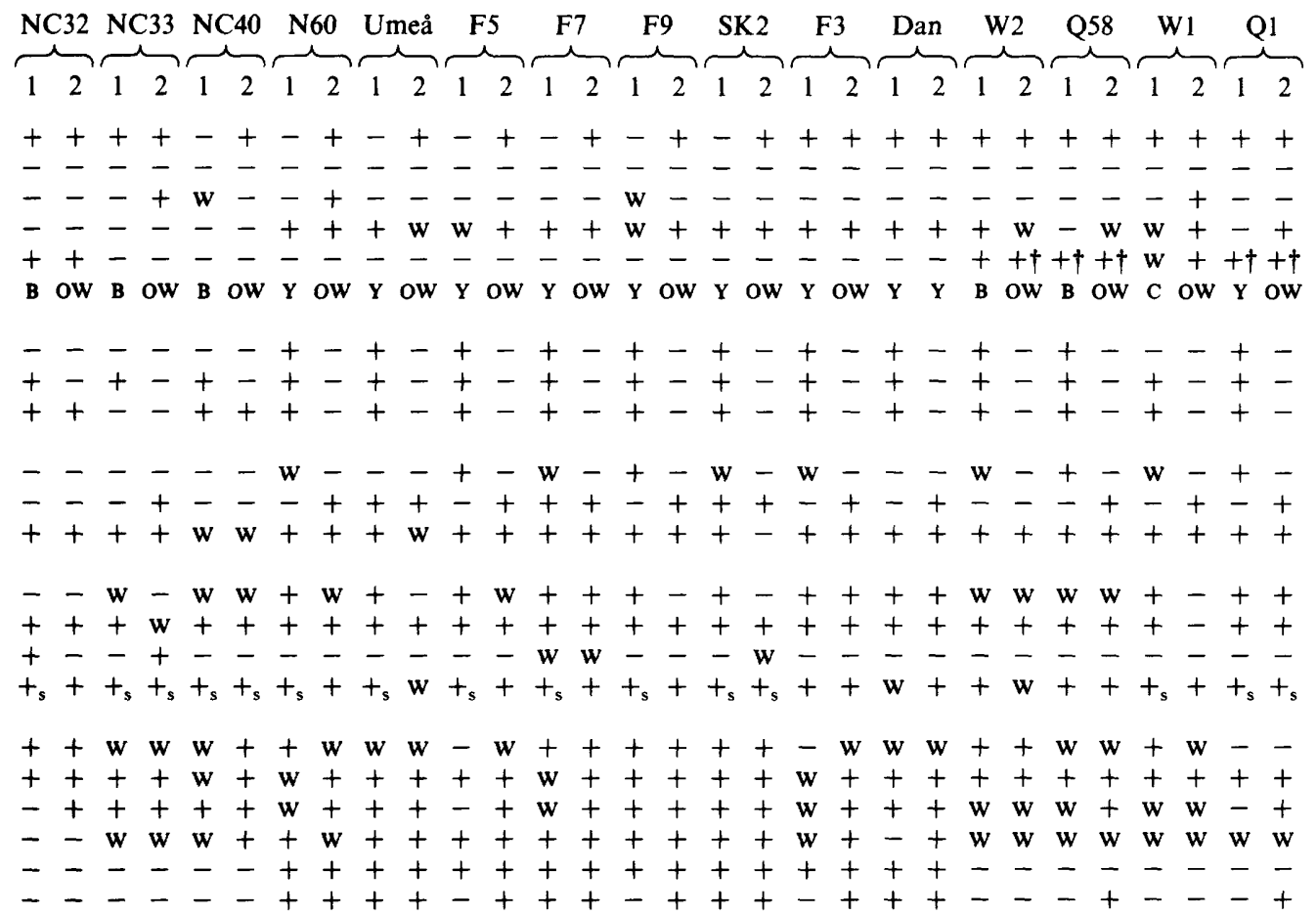

+ , Positive response; - , negative response; $w$, weak response.

* $\mathrm{n}$, no result; intense pigment diffusing in the medium hindered reading.

† Fluorescence of medium under UV light $(254$ and/or $366 \mathrm{~nm})$ disappeared within $10 \mathrm{~d}$ of incubation.

$\$ B$, Light/dark brown; C, cream; o, orange; ow, off-white; $P$, pink; $Y$, yellow.

$\S+$, Blue colonies, often surrounded by a clear zone. - , red or brownish colonies due to reduction of TTC to formazan. F5/2 did not appear to reduce TTC on NBTA and produced off-white colonies. However, on NA + TTC it produced red colonies indicating reduction of TTC.

$\|$ Heavy inoculum required; + , red or brown colonies; - , colourless colonies.

T Control by Frazier's (1926) method.

$\#+_{s}$, Positive response with Kohn's (Daguet, 1972) method, for liquefaction in tube within $10 \mathrm{~d}$ and with Frazier's (1926) method on gelatin/NA. +, Positive response for liquefaction in tube within $10 \mathrm{~d}$ and with Frazier's method on gelatin/NA. w, Positive response (weak) only with Frazier's method on gelatin/NA.

** Sierra's (1957) method.

Although tests for carbon source utilization and acidification using API strips were examined over $10 \mathrm{~d}$, there were no changes from results obtained within $6 \mathrm{~d}$.

Of 147 compounds tested, only 5 sugars were always acidified and 13 carbon sources utilized by all strains in the API tests. Variable results were obtained for the acidification of 11 and for the assimilation of 32 compounds. Most strains were able to assimilate these compounds when grown in the minimal medium API LRA but, particularly for the assimilation of DL-lactate and acetate, the addition of growth factors was sometimes required. All strains utilized citrate, acetate and DL-lactate when tested in Dye's (1968) medium; some strains did not utilize these compounds in the API tests.

All strains gave negative results for the acidification of melezitose when tested on API CH strips with API CHE medium (phenol red indicator). When tested in peptone water with bromocresol purple as indicator, most strains gave a weak, but definite, acidification up to $3 \mathrm{~d}$ after which the $\mathrm{pH}$ rose so that by $5 \mathrm{~d}$ all appeared negative. As no strain was able to grow on minimal medium with melezitose, we consider that the peptone water result may be an artefact and have scored all strains as negative for acidification of melezitose.

After $6 \mathrm{~d}$ a weak acidification of starch and glycogen was noticed for the secondary variants of 
Table 3. Acidification and assimilation characteristics distinguishing the two forms of Xenorhabdus strains

\begin{tabular}{|c|c|c|c|c|c|c|c|c|c|c|c|c|c|c|c|c|c|}
\hline \multirow{2}{*}{ Characteristic } & \multirow{2}{*}{$\begin{array}{l}\text { Strain } \quad \ldots \\
\text { Form } \quad . .\end{array}$} & \multicolumn{2}{|c|}{$\underbrace{\mathrm{C} 1}$} & \multicolumn{2}{|c|}{$\underbrace{\text { HI }}$} & \multicolumn{2}{|c|}{ Q614 } & \multicolumn{2}{|c|}{ A24 } & \multicolumn{2}{|c|}{$\underbrace{F 1}$} & \multicolumn{2}{|c|}{ NC116 } & \multicolumn{2}{|c|}{$\overbrace{}^{\mathrm{NC} 32}$} & \multicolumn{2}{|c|}{$\overbrace{}^{\mathrm{NC} 33}$} \\
\hline & & 1 & 2 & 1 & 2 & 1 & 2 & 1 & 2 & 1 & 2 & 1 & 2 & 1 & 2 & 1 & 2 \\
\hline Acidification* & & & & & & & & & & & & & & & & & \\
\hline Arbutin $(a)$ & & - & - & - & - & - & - & - & - & - & - & - & - & - & - & - & - \\
\hline D-Fructose $(b)$ & & - & + & + & - & + & + & + & + & + & + & + & + & - & w & + & + \\
\hline Gluconate $(a)$ & & $w$ & + & - & - & $\mathbf{w}$ & + & - & - & - & - & - & - & $\mathbf{w}$ & + & w & w \\
\hline Glycerol (a) & & w & + & + & + & + & + & + & + & + & w & + & + & + & + & + & + \\
\hline Inositol (a) & & + & + & + & + & + & + & $\mathbf{w}$ & w & w & w & w & w & - & - & - & - \\
\hline$(b)$ & & - & - & - & - & - & - & - & - & - & - & - & - & - & - & - & - \\
\hline 5-Keto-gluconate $(a)$ & & - & - & - & - & - & - & w & w & w & + & - & w & + & + & w & w \\
\hline$(b)$ & & - & - & - & - & - & - & - & - & - & + & - & - & - & - & - & - \\
\hline Ribose $(a)$ & & + & + & + & + & + & + & w & w & w & w & + & + & w & w & w & w \\
\hline$(b)$ & & - & - & + & + & - & - & - & - & - & - & - & - & - & - & - & - \\
\hline Salicin $(a)$ & & $w$ & + & - & - & $\mathbf{w}$ & + & - & - & - & - & - & - & - & - & - & - \\
\hline (b) & & - & + & - & - & - & - & - & - & - & - & - & - & - & - & - & - \\
\hline Trehalose $(a)$ & & w & w & + & w & - & + & + & + & + & + & + & + & + & + & + & + \\
\hline (b) & & - & - & - & - & - & - & + & + & $\mathbf{w}$ & + & w & w & + & + & + & + \\
\hline Assimilation $\dagger$ & & & & & & & & & & & & & & & & & \\
\hline Acetate & & + & + & + & + & + & + & - & - & - & w & - & + & - & - & w & + \\
\hline D- $\alpha$-Alanine & & w & - & w & w & w & - & - & - & - & - & - & - & - & - & $\mathbf{w}$ & + \\
\hline$L-\alpha-$ Alanine & & + & + & + & + & + & + & + & + & + & + & + & + & - & + & + & + \\
\hline Amygdalin & & $\mathbf{w}$ & + & - & - & - & - & - & - & - & - & - & - & - & - & - & - \\
\hline Arbutin & & w & + & w & + & w & w & - & - & - & - & - & - & - & - & - & - \\
\hline L-Arginine & & + & - & $\mathbf{w}$ & - & + & - & - & - & - & - & - & - & $\mathbf{w}$ & - & + & + \\
\hline L-Aspartate & & w & + & $\mathbf{w}$ & + & w & - & - & + & - & + & + & + & - & - & - & - \\
\hline n-Caproate & & - & - & - & - & - & - & - & - & - & - & - & - & - & - & - & - \\
\hline Citrate & & - & - & + & + & + & + & + & + & w & + & + & + & + & w & + & + \\
\hline Diaminobutane & & - & - & - & - & - & - & - & - & - & - & - & - & - & - & - & - \\
\hline D-Fructose & & + & + & + & + & + & + & + & + & + & + & + & + & $\mathbf{w}$ & w & w & w \\
\hline Fumarate & & $\mathbf{w}$ & + & + & + & + & + & + & + & + & + & + & + & + & + & + & + \\
\hline Glucosamine & & + & + & + & + & + & + & + & + & + & + & + & + & w & w & + & w \\
\hline DL-Glycerate & & $t$ & w & + & $\mathbf{w}$ & + & + & + & + & + & + & + & + & + & + & + & + \\
\hline Glycerol & & + & + & + & + & + & + & w & + & w & + & + & + & + & + & + & + \\
\hline Glycogen & & - & - & w & - & w & - & - & - & - & - & - & - & + & - & w & - \\
\hline L-Histidine & & + & - & + & + & + & + & - & + & - & - & + & + & + & - & + & $\mathbf{w}$ \\
\hline Inositol & & + & + & + & + & + & + & w & + & w & + & w & w & - & - & - & - \\
\hline 5-Keto-gluconate & & - & - & - & - & - & - & w & $\mathbf{w}$ & $\mathbf{w}$ & w & - & w & w & w & w & w \\
\hline 2-Oxoglutarate & & - & - & - & - & - & - & - & - & - & - & - & - & - & - & w & w \\
\hline D-Malate & & $\mathbf{w}$ & - & w & $\mathbf{w}$ & - & - & - & - & - & - & - & - & - & - & - & - \\
\hline L-Malate & & + & + & + & + & + & + & + & + & + & + & + & + & + & + & + & + \\
\hline L-Ornithine & & - & - & $\mathbf{w}$ & - & + & w & - & - & - & - & - & - & - & - & - & - \\
\hline Phenylacetate & & - & - & - & - & - & - & - & - & - & - & - & - & - & - & - & - \\
\hline L-Proline & & + & + & + & + & + & + & + & + & + & + & + & + & + & + & + & + \\
\hline Propionate & & - & - & - & - & - & - & - & w & - & w & + & + & - & - & w & - \\
\hline Pyruvate & & + & + & + & + & + & + & + & + & + & + & + & + & + & $\mathbf{w}$ & + & + \\
\hline Ribose & & + & + & + & + & + & + & - & - & - & - & + & $w$ & - & - & - & - \\
\hline Salicin & & w & + & - & - & w & + & - & - & - & - & - & - & - & - & - & - \\
\hline L-Serine & & + & + & + & + & + & + & + & + & + & + & + & + & w & - & $w$ & + \\
\hline Starch & & - & - & + & - & w & - & $\mathbf{w}$ & w & - & $w$ & + & + & + & - & $w$ & - \\
\hline Succinate & & w & + & + & + & + & + & + & + & + & + & + & + & + & + & + & + \\
\hline L-Threonine & & w & w & - & - & $\mathbf{w}$ & - & - & - & - & - & - & - & w & - & w & + \\
\hline Trehalose & & + & - & + & - & - & + & + & + & + & + & + & + & + & + & + & + \\
\hline L-Tyrosine & & + & + & + & + & + & + & - & - & - & - & - & - & - & - & w & w \\
\hline $\mathrm{n}$-Valerate & & - & - & - & - & - & - & - & + & - & + & + & + & $\mathbf{w}$ & - & - & - \\
\hline
\end{tabular}

strains W1, Q1, Umeå, NC33 and group B although none of these were found to hydrolyse, wholly or partially, these compounds. This acidification was considered too weak and delayed and was scored as negative.

Biochemical and physiological characteristics for which the two forms of any one strain varied are presented in Tables 2 and 3. 
Table 3. Continued

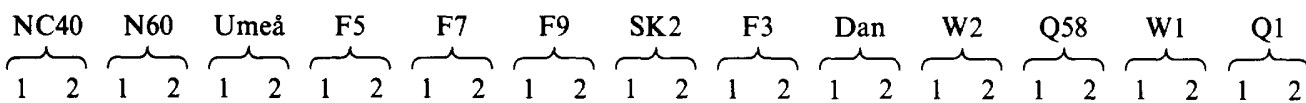

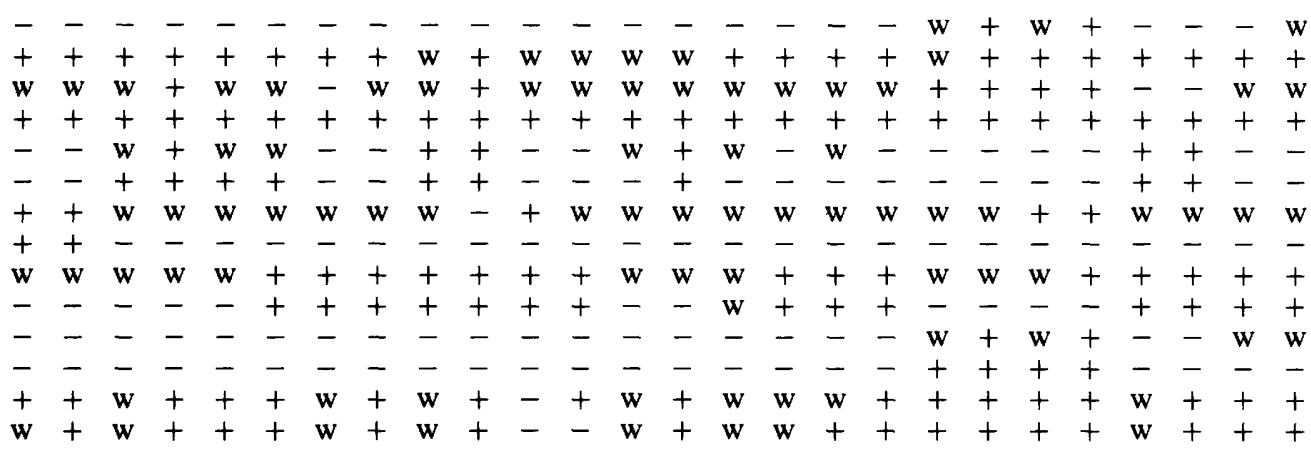

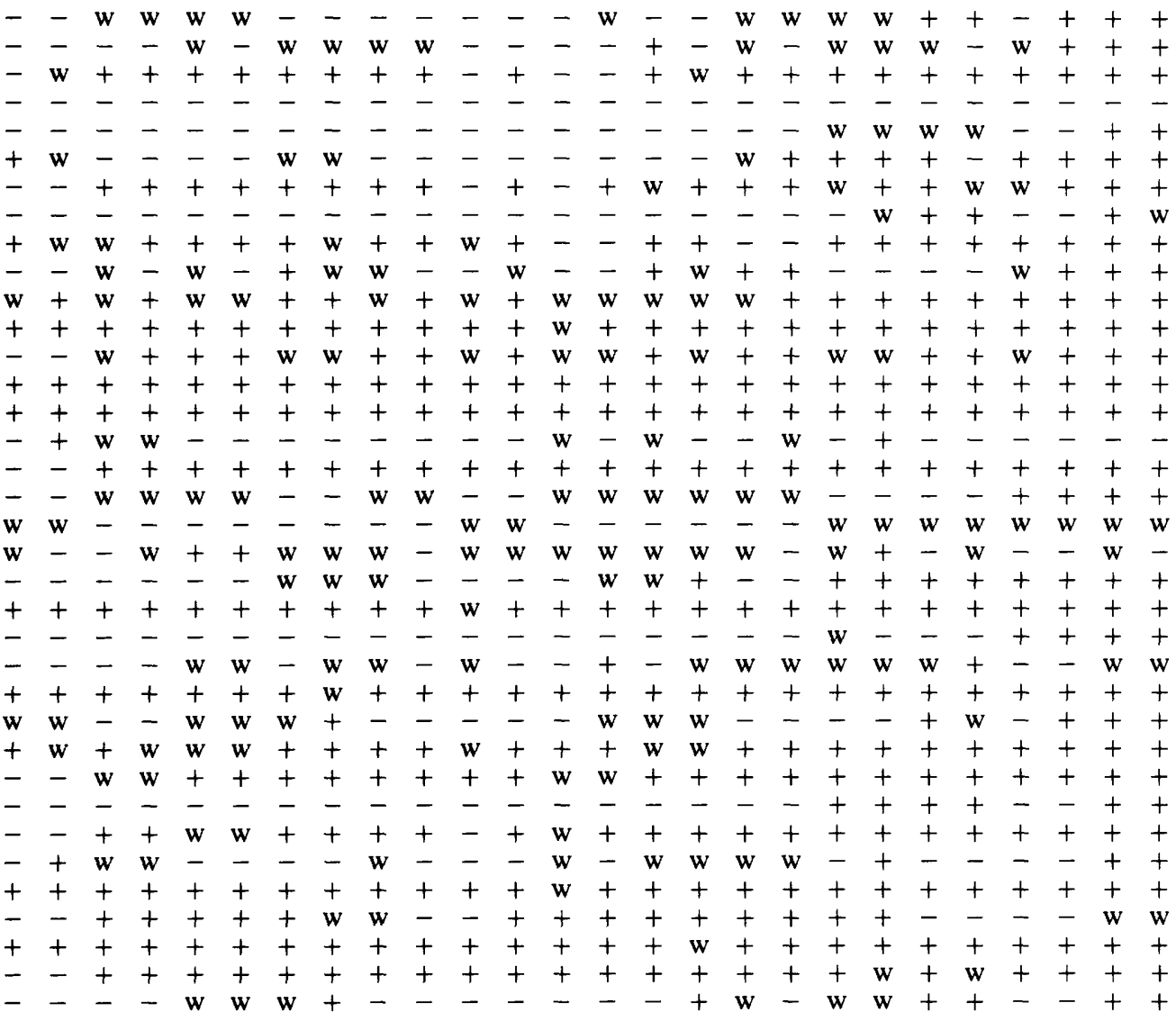

* (a) Done on medium API 50 CHE with phenol red as indicator $(\mathrm{pH}<6.8)$. + , Strongly positive reaction within $6 \mathrm{~d}$; w, weak response; -, negative (or extremely weak) response. $(b)$ Done on Dye's medium with bromocresol purple $(\mathrm{pH}<5 \cdot 8)$. + , Positive reaction within $6 \mathrm{~d}$; w, weak, but definite, acidification in the bottom of the tube; - , negative response.

$\dagger$ Done on medium API LRA with growth factors (see text). +, Turbidity within $6 \mathrm{~d}$; w, weak and delayed turbidity within $6 \mathrm{~d}$; - , no change within $6 \mathrm{~d}$. 


\section{DISCUSSION}

\section{Phase variation}

The occurrence of two forms has been shown to be a characteristic of the genus Xenorhabdus (Akhurst, 1983, 1986a,b). The primary form, defined as that which is carried within the infective-stage nematode, is unstable, producing the secondary form which may subsequently revert (Akhurst, 1980). The forms, which differ in their effect on nematode reproduction in vivo and in vitro, were distinguished by their differential pigmentation, adsorption of bromothymol blue from agar media (except $X$. nematophilus subsp. poinarii, Akhurst, 1986a) and antimicrobial activity (Akhurst, 1980, 1982 $b, 1986 a, b$ ). The current study has revealed some additional information on the forms.

A more widely useful indicator of primary form than adsorption of bromothymol blue was adsorption of neutral red from MacConkey agar. Adsorption of bromothymol blue proved to be useful for distinguishing the form of most strains ( $85 \%$ of our sample) but not those of Group C or strain W1. However, the primary forms of all strains were found to adsorb neutral red from MacConkey agar, forming either red (Groups A and C) or brown colonies.

It is suggested that the differential adsorption indicates differences in external material produced around the cell body by the two forms. Like Xenorhabdus, Neisseria gonorrhoeae displays variation in the opacity and form of colonies. The differences in $N$. gonorrhoeae are affected by a protein on the outer surface of the cell wall that is independent of the major outermembrane protein and pili (Swanson, 1978). Adsorption of the dye Congo red by Yersinia enterocolitica was also shown to be related to surface characteristics (Robins-Browne et al., 1986). There are indications that the differential adsorption of dye by the two forms of Xenorhabdus is also due to surface differences. Examination by light microscope indicated that the dye was adsorbed onto, rather than absorbed into, the cells (R. J. Akhurst, unpublished data). Preliminary electron microscopic studies also indicate that the primary forms of strains from groups A and B have a material overlaying the external layer of cell membrane and the fimbriae that is stained by ruthenium red (N. E. Boemare \& M. Brehelin, unpublished results). The suggestion of differences in the cell coat is consistent with our observations that primary forms of group A strains were sticky whereas those of the secondary form were not and that primary forms of all the other strains were difficult to disperse in liquid whereas the secondary forms dispersed easily. In general, the two forms could also be distinguished by lecithinase activity. Primary form variants produced lecithinase whereas secondary did not (except for the strains NC116, Dan and Umeå and those of Group C where neither form produced lecithinase).

The scintillation count data presented here confirm the observation of Akhurst (1980) that, in the bioluminescent strains, the primary forms were more strongly bioluminescent than their corresponding secondary forms. However, bioluminescence may not be a good indicator of form because its intensity also varies considerably between strains.

The forms of various strains gave differential responses (either $+/-$ or $w /+$ ) to many other tests. The differential responses for any one of these tests were not consistent within any recognizable group of strains and so they were of no value in distinguishing the forms. However, these differences may explain some of the discrepancies between earlier studies where recognition of the forms was not made.

\section{Methodology}

Tests to determine biochemical characteristics must be carried out using methods that are appropriate for Xenorhabdus.

All strains were positive for citrate utilization when the medium of Dye (1968) was used (Table 2). This medium contains $0 \cdot 1 \%$ yeast extract, which provides growth factors required for the initiation of Xenorhabdus growth. When Simmons citrate synthetic medium was used, the results were variable (Table 2; Farmer, 1984; Grimont et al., 1984). Similarly, acetate and DLlactate were utilized by all strains when tested in Dye's medium (Dye, 1968) but only by some strains when tested in the API medium. 
Grimont et al. (1984) detected no phenylalanine or tryptophan deaminase activity in their Xenorhabdus strains and Farmer (1984) found no phenylalanine deaminase in $X$. nematophilus and in only $11-25 \%$ of $X$. luminescens strains. Akhurst (1983) showed that the test for phenylalanine deaminase activity gave inconsistent results with Xenorhabdus if conducted at $2 \mathrm{~d}$ as recommended (Difco Laboratories, 1962). In the current study, use of the more sensitive ferric perchloride reagent and testing at $5 \mathrm{~d}$ revealed differences in production of phenylpyruvic and indolpyruvic acids by Xenorhabdus. Since these tests were not conducted at $2 \mathrm{~d}$ as recommended, they cannot be interpreted as indicative of phenylalanine (or tryptophan) deaminase activity. They are, nevertheless, useful for the intrageneric taxonomy of Xenorhabdus.

Previous workers have also disagreed on the ability of Xenorhabdus to liquefy gelatin (Khan \& Brooks, 1977; Thomas \& Poinar, 1979, 1983; Akhurst, 1983; Farmer, 1984; Grimont et al., 1984). This study showed that, although at least one variant of each strain liquefies gelatin, the extent of liquefaction varied considerably (Table 2). The most sensitive test for gelatin liquefaction was that where bacteria were grown on gelatin nutrient agar and then flooded with Frazier's (1926) reagent to precipitate the remaining protein.

There has been considerable variation in listing carbohydrates acidified by Xenorhabdus (Khan \& Brooks, 1977; Thomas \& Poinar, 1979, 1983; Akhurst, 1983; Farmer, 1984; Grimont et al., 1984). Some of the variation can be attributed to the choice of $\mathrm{pH}$ indicator (e.g. phenol red, pK 6.8, and bromocresol purple, pK 5.8) but some may also be due to the basal medium. Many strains in this study gave short-lived positive results for acidification of melezitose when tested in peptone water with bromocresol purple as indicator but negative results when tested in API CHE, which uses a more sensitive indicator of acidification (phenol red). We have scored acidification of melezitose as negative because it was not assimilated by any strain when tested in the API medium. If a more sensitive test of assimilation can be devised, this scoring may have to be reviewed.

There are no obvious reasons for some of the disparities in the results reported by Grimont $e t$ al. (1984), Farmer (1984) and those recorded here. Farmer found that none of his $X$. nematophilus strains and only $11-25 \%$ of his $X$. luminescens strains acidified maltose and no strains acidified trehalose. Grimont et al. (1984) found that $>50 \%$ of their strains acidified maltose and that strains in each of their three groups acidified trehalose. Only a proportion of the strains examined by Grimont et al. (1984) and Farmer (1984) acidified glucose; both variants of all of our strains acidified glucose. One difference between this study and those of Farmer (1984) and Grimont et al. (1984) was the source of the bacteria. The primary form variants of our strains were isolated from their nematode associates immediately prior to the study and the secondary form variants were obtained from them. Many of the bacteria examined by Grimont et al. (1984) were obtained from other workers; the source of Farmer's (1984) strains is unknown to us. Differences in handling the cultures prior to these studies may have resulted in a greater chance of contamination of, or of revealing potential genetic diversity in, those strains with longer and more varied cultural history.

\section{CONCLUSION}

This study has shown that some of the differences between earlier studies of the characteristics of Xenorhabdus can be attributed to variation in the methods employed and some to differences between the primary and secondary forms.

Two forms can arise in all Xenorhabdus strains in vitro after subculturing or during monoxenic culture with the nematode associate and, in some strains, in vivo during nematode reproduction within an insect host (Akhurst, 1980, 1986a,b). In all strains the primary form and, at least in the $X$. nematophilus subspecies nematophilus and bovienii the secondary form, may produce the alternate form. The difference between the two forms are obviously more than a colony dimorphism and suggest a different conception of the variation. We propose to define this as a phase phenomenon in keeping with Trüper \& Kramer (1981) who state that the term phase 'should be restricted to well-defined stages of naturally occurring alternating variations'. Phase I 
variants produce antimicrobial factors, adsorb neutral red from MacConkey agar and, in most strains, produce lecithinase. Phase II variants have none of these activities and in pigmented strains are noticeably less pigmented than phase I variants.

The authors wish to thank Institut National de la Recherche Agronomique and CSIRO for financial support enabling N. E. B. to work in Australia. We thank Dr M. Brehélin for discussion on the text. We also acknowledge the technical assistance of Messrs J. G. Moss, V. S. Patel, M. A. Stanfield and J. Luciani and of Ms E. Bonifassi for technical assistance.

\section{REFERENCES}

AKHURST, R. J. (1980). Morphological and functional dimorphism in Xenorhabdus spp., bacteria symbiotically associated with the insect pathogenic nematodes Neoaplectana and Heterorhabditis. Journal of General Microbiology 121, 303-309.

AkHURST, R. J. (1982a). A Xenorhabdus sp. (Eubacteriales: Enterobacteriaceae) symbiotically associated with Steinernema kraussei (Nematoda: Steinernematidae). Revue de nematologie 5, 277-280.

AKHURST, R. J. (1982b). Antibiotic activity of Xenorhabdus spp., bacteria symbiotically associated with insect pathogenic nematodes of the families Heterorhabditidae and Steinernematidae. Journal of General Microbiology 128, 3061-3066.

AKHURST, R. J. (1982c). Bacterial symbionts of insect pathogenic nematodes of the families Steinernematidae and Heterorhabditidae. PhD thesis, University of Tasmania, Hobart, Australia.

AKHURST, R. J. (1983). Taxonomic study of Xenorhab$d u s$, a genus of bacteria symbiotically associated with insect pathogenic nematodes. International Journal of Systematic Bacteriology 33, 38-45.

AKHURST, R. J. (1986a). Xenorhabdus nematophilus subsp. poinarii: its interaction with insect pathogenic nematodes. Systematic and Applied Microbiology 8 , 38-45.

AKHURST, R. J. (1986b). Xenorhabdus nematophilus subsp. beddingii (Enterobacteriaceae) a new subspecies of bacteria mutualistically associated with entomopathogenic nematodes. International Journal of Systematic Bacteriology 36, 454-457.

BEDDING, R. A. (1981). Low cost in vitro mass production of Neoaplectana and Heterorhabditis species (Nematoda) for field control of insect pests. Nematologica 27, 109-114.

BEDDING, R. A. (1984). Large scale production, storage and transport of the insect-parasitic nematodes Neoaplectana spp. and Heterorhabditis spp. Annals of Applied Biology 104, 117-120.

Bedding, R. A. \& AKhurst, R. J. (1975). A simple technique for the detection of insect parasitic rhabditid nematodes in soil. Nematologica 21, 109 110.

Bedding, R. A. \& Molyneux, A. S. (1982). Penetration of insect cuticle by infective juveniles of Heterorhabditis spp. (Heterorhabditidae: Nematoda). Nematologica 28, 354-359.

BIRD, A. F. \& AKHURST, R. J. (1983). The nature of the intestinal vesicle in nematodes of the family Steinernematidae. International Journal of Parasitology 13, 599-606.

BOEMARE, N. (1983). Recherches sur les complexes nemato-bacteriens entomopathogenes: etude bactério- logique, gnotobiologique et physiopathologique du mode d'action parasitaire de Steinernema carpocapsae Weiser (Rhabditida: Steinernematidae). Thesis, Université des Sciences, Montpellier, France.

Boemare, N., Laumond, C. \& LuCiani, J. (1982). Mise en évidence d'une toxicogenèse provoquée par le nématode axénique entomophage Neoaplectana carpocapsae Weiser chez l'insecte axenique Gallerio mellonella L. Comptes rendus de l'Academie des sciences, Series III 295, 543-546.

Boemare, N., Louis, C. \& KuHL, G. (1983). Etude ultrastructurale des cristaux chez Xenorhabdus spp., bactéries infeodées aux nématodes entomophages Steinernematidae et Heterorhabditidae. Comptes rendus des séances de la Société de biologie 177, 107 115.

Burman, M. (1982). Neoaplectana carpocapsae: toxin production by axenic insect parasitic nematodes. Nematologica 28, 62-70.

DAGUET, G.-L. (1972). Techniques en Bactériologie. 1. Aérobies. Paris: Flammarion.

DifCO LABORATORIES (1962). Difco Supplementary Literature. Detroit, Michigan: Difco Laboratories.

DYe, D. W. (1968). A taxonomic study of the genus Erwinia. I. The 'amylovora' group. New Zealand Journal of Science 11, 590-607.

FARMER, J. J. (1984). Other genera of the family Enterobacteriaceae. In Bergey's Manual of Systematic Bacteriology, vol. I, pp. 506-511. Edited by N. R. Kreig. Baltimore, London: Williams and Wilkins.

Frazier, W. C. (1926). A method for the detection of changes in gelatin due to bacteria. Journal of Infectious Diseases 39, 302.

Götz, P., Boman, A. \& Boman, H. G. (1981). Interactions between insect immunity and an insectpathogenic nematode with symbiotic bacteria. Proceedings of the Royal Society B212, 333-350.

Grimont, P. A. D., Steigerwalt, A. G., Boemare, N., Hickman-Brenner, F. W., Deval, C., GrIMONT, F. \& BRENNER, D. J. (1984). Deoxyribonucleic acid relatedness and phenotypic study of the genus Xenorhabdus. International Journal of Systematic Bacteriology 34, 378-388.

KhAN, A. \& BRoOKs, W. M. (1977). A chromogenic bioluminescent bacterium associated with the entomophilic nematode Chromonema heliothidis. Journal of Invertebrate Pathology 29, 253-261.

MILSTEAD, J. E. (1979). Heterorhabditis bacteriophora as a vector for introducing its associated bacteria into the haemocoel of Galleria mellonella larvae. Journal of Invertebrate Pathology 33, 324-327.

PoINAR, G. O. (1966). The presence of Achromobacter nematophilus in the infective stage of a Neoaplectana 
sp. (Steinernematidae: Nematoda). Nematologica 12, 105-108.

PoINAR, G. O. (1979). Nematodes for Biological Control of Insect Pests. Boca Raton, Florida: CRC Press.

Poinar, G. O. \& Thomas, G. M. (1966). Significance of Achromobacter nematophilus Poinar and Thomas (Achromobacteraceae: Eubacteriales) in the development of the nematode, DD136 (Neoaplectana sp.: Steinernematidae). Parasitology 56, 385-390.

PoINAR, G. O. \& Thomas, G. M. (1967). The nature of Achromobacter nematophilus as an insect pathogen. Journal of Invertebrate Pathology 9, 510-514.

Poinar, G. O., Thomas, G. M., VeremchuK, G. V. \& PINNOCK, D. E. (1971). Further characterisation of Achromobacter nematophilus from American and Soviet populations of the nematode Neoaplectana carpocapsae Weiser. International Journal of Systematic Bacteriology 21, 78-82.

Ramia, S., Neter, E. \& Brenner, D. J. (1982). Production of enterobacterial common antigen as an aid to classification of newly discovered species of the families Enterobacteriaceae and Vibrionaceae. International Journal of Systematic Bacteriology 33, 395-398.

Robins-Browne, R. M., Prpic, J. K. \& Davey, R. B. (1986). Influence of the virulence plasmid and the Congo red reaction on the antimicrobial susceptibility of Yersinia species. Journal of Antimicrobial Chemotherapy 17, 553-557.

SiERRA, G. (1957). A simple method for the detection of lipolytic activity of micro-organisms and some observations on the influence of the contact between cells and fatty substances. Antonie van Leeuwenhoek 23, 15-22.

SKERMAN, V. B. D. (1967). A Guide to the Identification of the Genera of Bacteria, 2nd edn. Baltimore: Williams \& Wilkins.

SWANSON, J. (1978). Studies on gonococcus infection. XIV. Cell wall protein differences among color/ opacity colony variants of Neisseria gonorrhoeae. Infection and Immunity 21, 292-302.

Thomas, G. M. \& Poinar, G. O. (1979). Xenorhabdus gen. nov., a genus of entomopathogenic nematophilic bacteria of the family Enterobacteriaceae. International Journal of Systematic Bacteriology 29, 352360.

Thomas, G. M. \& Poinar, G. O. (1983). Amended description of the genus Xenorhabdus Thomas and Poinar. International Journal of Systematic Bacteriology 33, 878-879.

TrüPER, H. G. \& KRAmer, J. (1981). Principles of characterisation and identification of prokaryotes. In The Prokaryotes, vol. I, pp. 173-193. Edited by M. Starr, H. Stolp, A. Balows \& H. Schlegel. Berlin: Springer.

Wouts, W. M., Mrácek, Z., Gerdin, S. \& Bedding, R. A. (1982). Neoaplectana Steiner, 1929; a junior synonym of Steinernema Travassos, 1927 (Nematoda: Rhabditida). Systematic Parasitology 4, 147154. 